\title{
PENGARUH PEMBERIAN MINYAK BUAH MERAH (Pandanus conoideus Lam.) TERHADAP DEGENERASI SEL GINJAL MENCIT (Mus musculus) YANG DIPAPAR PLUMBUM
}

\author{
Siska Aprilianti ${ }^{1}$, Maratun Janah ${ }^{1}$, Candra Dwi Atma ${ }^{1}$, Novarina Sulsia Ista'In Ningtyas ${ }^{1 *}$ \\ ${ }^{1}$ Fakultas Kedokteran Hewan, Universitas Pendidikan Mandalika \\ *Email: novarina.sullsia@gmail.com
}

\begin{abstract}
Plumbum $(\mathrm{Pb})$ pollution in environment can cause dangerous for animal. Plumbum enter the body through oral cavity and was excreted by kidney and can effect to the kidney function. Defect in kidney can make distraction of metabolism. An effort to prevent deffect in kidney that cause by plumbum can be used antioxidant from Red Fruit plant (Padanus conoideus Lam). The aim of this research was to know the effect of Red Fruit plant with the degrees of kidney cell degeneration that was exposed by plumbum. Type of this research was experimental research that use complete random design with 4 treatment, P0 (aquadest 0,5 ml), P1 (Pb 0,01 mg), P2 (was given with Red Fruit Oil 0,3 $\mathrm{ml}$ and $\mathrm{Pb} 0,01 \mathrm{mg}$ ), P3 (was given with Red Fruit Oil 0,8 $\mathrm{ml}$ and $\mathrm{Pb0}, 01 \mathrm{mg}$ ). The data was analyzed by Kruskal Wallis using SPSS and followed with Mann-Whitney test. The result of this research show that there were significant difference between $P 0$ and $P 1, P 0$ and $P 2, P 0$ and $P 3, P 1$ and $P 3$ $(P<0,05)$, but did not showed significant difference $(p>0.05)$ with P2 and P3. Base on this research can be concluded that giving red fruit oil can decrease the degrees of cell degeneration in mouse kidney that was exposed by plumbum.
\end{abstract}

Keywords : antioxidant, kidney degeneration, Plumbum, red fruit plant

\section{PENDAHULUAN}

Plumbum $(\mathrm{Pb})$ merupakan salah satu bahan pencemaran bersumber dari gas kendaraan bermotor dan limbah industry yang dapat ditemukan di air, udara dan tanah (Naria, 2005). Intoksikasi plumbum melalui lingkungan sudah dikenal sejak lebih dari 2000 tahun yang lalu. Pencemaran udara di perkotaan diperkirakan $70 \%$ disebabkan oleh aktivitas kendaraan bermotor. Asap kendaraan bermotor dapat mengeluarkan partikel pb yang kemudian masuk atau mencemari ke dalam makanan yang dijajankan di pingir jalan atau dapat terserap manusia (Cahyadi, 2004). Pencemaran plumbum $(\mathrm{Pb})$ di lingkungan dapat menimbulkan bahaya bagi kesehatan baik pada manusia,hewan, tanaman maupun lingkungan. Plumbum bersifat karsinogenik, dapat menyebabkan mutasi terurai dalam jangka waktu yang lama dan toksisitasnya tidak berubah (Brass and Strauss 1981).Plumbum masuk ke dalam organ melalui oral dan di ekskresi di ginjal dan dapat mempengaruhi fungsi ginjal yang merupakan suatu organ yang sangat penting untuk mengatur fungsi, mempertahankan volume, komposisi dan distribusi cairan tubuh serta mengeluarkan hasil metabolisme tubuh yang sudah tidak digunakan. Kerusakan pada ginjal membuat sisa metabolisme dan air tidak dapat di eksresikan. Dalam kadar tertentu, Pb tersebut dapat meracuni tubuh, kemudian menimbulkan kerusakan jaringan. Plumbum juga dapat menyebabkan stres oksidatif dan meningkatkan pembentukan radikal bebas dan dapat menurunkan sistem antioksidan di jaringan Stres oksidatif dapat mengakibatkan kerusakan molekul di dalam sel (Riwayanti, dkk 2014).

Upaya untuk mencegah kerusakan ginjal yang diakibatkan oleh timbal yaitu dapat digunakan antioksidan yang tinggi yang berasal dari tanaman Buah merah (Padanus conoideus Lam) yang merupakan salah satu tanaman yang berpotensi dalam mengobati berbagai penyakit. Buah merah merupakan buah endemik Papua yang mengandung senyawa antioksidan untuk anti radikal bebas karena mengandung tokoferol $11.000 \mathrm{ppm}$ dan betakaroten 12.000 ppm (Palupi dan Martosupono, 2009). Kandungan pada minyak buah merah ini berpengaruh juga dalam meningkatkan jumlah folikel matang pada mencit infertile (Ningtyas, 2017). Hal ini berkaitan dengan peran tokoferol dan betakaroten sebagai antioksidan alami dengan adanya gugus - $\mathrm{OH}$ pada tokoferol serta 
ikatan rangkap pada betakaroten dapat menghambat dan menetralisir radikal bebas (Murray et al., 2009).

Dampak paparan plumbum terhadap kerusakan ginjal dan manfaat kandungan antioksidan buah merah diharapkan dapat mengurangi kerusakan pada histopatologi ginjal sehingga penelitian ini bertujuan untuk mengetahui pengaruh minyak buah merah terhadap kerusakan ginjal salah satunya adalah degenerasi ginjal.

\section{METODE}

\section{Hewan dan perlakuan}

Penelitian ini menggunakan 20 ekor mencit dengan BB 20g dibagi menjadi 4 kelompok dengan 5 ulangan. Minyak buah merah yang dipakai pada penelitian ini adalah minyak buah merah yang telah siap pakai dan $\mathrm{Pb}$ diberikan secara oral dengan sonde lambung selama 14 hari. P0 diberikan aquades setiap ekornya sebanyak 0,5 ml/hari, $\mathrm{P} 1$ diberikan $\mathrm{Pb}$ setiap ekornya sebanyak $0,01 \mathrm{mg} /$ hari, $\mathrm{P} 2$ diberikan minyak buah merah $0,3 \mathrm{ml}$ dan $\mathrm{Pb} 0,01 \mathrm{mg} /$ hari dan kelompok P3 diberikan minyak buah merah

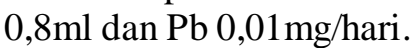

\section{Pembuatan dan Pengamatan Preparat}

Organ ginjal mencit yang sudah dikoleksi kemudian difiksasi menggunakan formalin $10 \%$ setelah itu dilakukan dehidrasi dengan alcohol bertingkat, kemudian dilakukan clearing menggunakan xylol. Tahap selanjutnya adalah tahap infiltrasi dan embedding menggunakan paraffin cair dan paraffin blok kemudian dilakukan sectioning dan penempelan pada objek glass. Preparat kemudian diwarnai dengan pewarnaan HE.Pengamatan preparat mengunakan mikroskop cahaya dengan pembesaran 400x pada lima lapangan pandang yang berbeda dimulai dari sudut kiri, kanan, bagian atas, bagian bawah, dan bagian tengah dari preparat histopatologi ginjal mencit. Pemberian skor tingkat degenerasi mengunakan Skoring berdasarkan Suhita dkk (2013) yaitu Skor 0 tidak ditemukan degenerasi Skor 1 degenerasi tubulus atau fokal Skor 2 degenerasi merata.

\section{Analisis Data}

Data hasil pemeriksaan sediaan histopatologi dianalisis secara statistik nonparametrik Kruskal Wallis dan apabila terdapat perbedaan yang nyata ( $<<0,05$ )dilanjutkan dengan uji Mann-Whitney. Semua analisis menggunakan SPSS

\section{HASIL}

Hasil analisis pemberian minyak buah merah dan di paparkan $\mathrm{Pb}$ terhadap degenerasi sel tubulus ginjal mencit mengunakan uji Kruskal-Wallis Test menunjukan bahwa signifikansi atau p-value adalah 0,005 (P < $0,05)$, menunjukkan adanya perbedaan nyata, sehingga pengujian dilanjutkan dengan uji Mann - Whitney. Hasil uji Mann - Whitney. Rata - rata Degenerasi Sel Tubulus Ginjal Mencit.

Tabel 1. Hasil Skoring Degenerasi Sel Tubulus

\begin{tabular}{cc}
\hline Perlakuan & $\overline{\mathbf{X}} \pm$ SD \\
\hline P0 & $0,00^{\mathrm{a}} \pm 0,000$ \\
\hline P1 & $1,76^{\mathrm{d}} \pm 0,167$ \\
\hline P2 & $1,08^{\mathrm{bc}} \pm 0,179$ \\
\hline P3 & $0,88^{\mathrm{b}} \pm 0,666$ \\
\hline
\end{tabular}

Superskrip yang berbeda pada kolom yang sama menunjukkan perbedaan yang nyata pada taraf kepercayaan $\alpha=0,05(\mathrm{p}<0,05)$.

Pada tabel 1 dapat dilihat bahwa mencit yang mengalami degenerasi ginjal paling parah pada perlakuan $\mathrm{P} 1$ dan paling ringan pada perlakuan P0. Perlakuan P0 dan P1, P0 dan P2, P0 dan P3 terdapat perbedaan yang nyata $(\mathrm{P}<0,05)$. Perlakuan $\mathrm{P} 1$ dan $\mathrm{P} 2$ terdapat perbedaan nyata $(\mathrm{P}<0,05)$. Perlakuan $\mathrm{P} 1$ dan P3, P3 terdapat perbedaan nyata $(\mathrm{P}<0,05)$, sedangkan perlakuan $\mathrm{P} 2$ dan $\mathrm{P} 3$ tidak terdapat perberbedaan yang nyata $(\mathrm{P}>0,05)$. Degenerasi sel tubulus ginjal mencit dapat dilihat pada Gambar 1 .

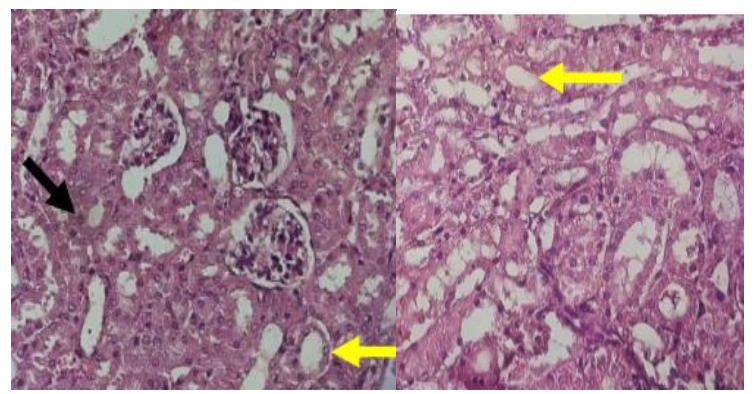

Gambar 1. Gambar mikroskopis ginjal mencit perbesaran 400x. Tubulus (panah hitam) terlihat normal, tubulus (panah kuning) terdapat sel tubulus yang mengalami degenerasi. 


\section{PEMBAHASAN}

Respon sel terhadap paparan toksik umumnya menyebabkan perubahan pada ginjal yang memperlihatkan degenerasi tubulus ginjal (Fahrimal dkk.,2016). Hasil dari penelitian ini menunjukan bahwa degenerasi paling tinggi terjadi pada kelompok mencit yang diberikan $\mathrm{Pb}$ tanpa minyak buah merah, dibandingkan dengan kelompok yang diberikan $\mathrm{Pb}$ dengan minyak buah merah. Adanya akumulasi zat toksik, dalam hal ini $\mathrm{Pb}$ pada ginjal dapat menyebabkan terganggunya proses eksresi sehingga menyebabkan gangguan struktur sel ginjal(Schnellman, 2001). Plumbum juga memicu terjadinya ROS dan terbentuknya ROS dalam tubuh kita disebabkan oleh stres oksidatif. ROS merupakan radikal bebas yang berada dalam tubuh yang terdiri dari satu atau lebih elektron yang tidak berpasangan sehinga tidak stabil dan reaktif, untuk menstabilkan maka ROS akan mengoksidasi organ yang dikenal dengan keadaan stres oksidatif yang memicu terjadinya peroksidasi lipid, yaitu suatu proses dimana radikal bebasyang bersifat lipofilik merusak membran sel yang terdiri atas Poly Unsaturated Fatty Acid ( PUFA). Degenerasi sel terjadi akibat adanya kerusakan pada membran sel, rusaknya membran akan memicu terjadinya oksidasi asam amino dan peningkatan permibilitas membran sel, sehingga reaksi seluler tidak berjalan sebagaimana mestinya (Allen, 2000).

Kelompok yang diberikan $\mathrm{Pb}$ dan diberikan minyak buah merah $0,3 \mathrm{ml}$ dan kelompok yang diberikan $\mathrm{Pb}$ danberikanminyak buah merah $0,8 \mathrm{ml}$ menunjukkan tingkat degenerasi yang lebih rendah dibandingkan dengan kelompok yang diberikan $\mathrm{Pb}$ tanpa diberikan minyak buah merah. Hal ini disebabkan karena pemaparan $\mathrm{Pb}$ yang diberikan disertai dengan pemberian minyak buah merah. Minyak buah merah mengandung zat aktif yang relatif tinggi, karoten dan betakaroten. Minyak buah merah juga memiliki kandungan asam lemak tidak jenuh dalam jumlah yang tinggi seperti asam oleat serta mengandung antioksidan yang berperan dalam menangkal oksidasi radikal bebas dalam tubuh. Kandungan minyak buah merah berpengaruh terhadap jumlah folikel de Graff pada mencit yang dipapar plumbum (Ningtyas dkk., 2019). Kegunaan utama antioksidan ini untuk menghentikan atau memutus reaksi berantai dari radikal bebas yang terdapat dalam tubuh (Swantara dan Parwata, 2011). Adapun pendapat Utomo dkk (2008) tentang kegunaan antioksidan ini adalah untuk menetralkan radikal bebas sehingga dapat melindungi sistem biologi tubuh dari efek merugikan yang timbul dari proses ataupun reaksi yang menyebabkan oksidasi yang berlebihan.

Fungsi senyawa betakaroten dikenal sebagai antioksidan penangkal yang kuat bagi oksigen reaktif. Selain itu, betakaroten juga mampu meningkatkan kekebalan tubuh karena intraksi vitamin dengan protein (asam-asam amino) yang berperan dalam pembentukan antibodi (Sakkir dkk.,2008) Betakaroten memiliki kelebihan elektron pada struktur kimianya, maka partikel radikal bebas yang pada awalnya kekurangan elektron dari senyawa betakaroten. Tokoferol yang terkandung dalam minyak buah merah merupakan antioksidan alami yang mampu untuk memperlambat proses oksidatif (Rohman dan Sugeng, 2012).

\section{KESIMPULAN}

Berdasarkan penelitian yang telah dilakukan dapat disimpulkan pemberian minyak buah merah dapat mengurangi tingkat degenerasi sel ginjal mencit yang dipapar Plumbum $(\mathrm{Pb})$.

\section{REFERENSI}

Allen, G. 2000. Marine Fishes Of South-East Asia. Pariplus edition (HK) Ltd. Australia

Brass, G.M. and W. Strauss. 1981. Airpollution Control. John Willey \& Sons. New York.

Budi Utomo, Anang. Suprijono, Agus. Risdianto, Ardan. 2008. "Uji AktivitasAntioksidan Kombinasi Ekstrak Sarang Semut (Myrmecodia pendans) dan Ekstrak Teh Hitam (Camellia sinensis O.K.var.assamica (mast.)) DenganMetode DPPH (1,1difenil-2-pikrilhidrazil)", Sekolah Tinggi Ilmu FarmasiYayasan Pharmasi Semarang

Cahyadi, M. 2004. Bahaya Pencemaran Timbal pada Makanan dan Minuman. 
Bandung: Fakultas Teknik Unpas Departemen Farmasi Pascasarjana ITB.

Fahrimal, Y., Rahmiwati, dan D. Aliza. 2016. Gambaran histopatology ginjal tikur putih (Rattus norvegicus) jantan yang diinfeksikan Trypanosoma evansi dan diberi ekstrak daun sernai (Wedelia biflora). Jurnal Medika Veterineria. 10(2):166-170.

Murray R.K., Granner D.K., Rodwell V.W. 2009. Biokimia Harper. Edisi 27. Penerbit B uku Kedokteran EGC. Jakarta.

Naria E. 2005. Mewaspadai Dampak Bahan Pencemar Timbal $(\mathrm{Pb})$ di Lingkungan Terhadap Kesehatan. Jurnal Komunikasi Penelitian. 17(4): 2

Ningtyas, N.S.I., Kunti T, Alfiana laili D.A. 2019. Proteksi Minyak Buah Merah (Padanus conoideus Lam) Terhadap Jumlah Folikel yang di Papar Plumbum. vol.5.No.4 (2019). Hal 7-9

Ningtyas,N.S.I.. 2017. Pengaruh Pemberian Minyak Buah Merah Terhadap Histopatologi Folikel De Graap Pada Mencit Model Infertil. Jurnal Sangkareang Mataram volume.3,No.3. Hal 36-38

Palupi, I.A. dan Martosupono, M. 2009. Buah Merah : Potensi dan Manfaatnya Sebagai Antioksidan. Jurnal Tumbuhan Obat Indonesia 2(1):42-48.

Riwayanti I, Hartati I, Purwanto H, Suwardiyono. Prosiding saseminar Nasional Aplikasi Sains \& Teknologi (SNAST); 2014 Nov 15; Yogyakarta. Indonesia: 1979-911X. SNAST; 2014.

Rohman, R Sugeng, YB Che Man. 2012. (Padanus conoideus Lam) oil. Internatioonal Food Research Journal. 2012; 19(2):563-7

Sakkir B, Khidri, M.A dan Sjafruddin Ahmad. 2008. Kadar Timbal Dalam Darah Pada Anak-anak di kota Makassar. Jurnal Kesehatan Masyarakat Madani 01(02) 110

Schnellman R. G, Goldstein R. S., 2001, Toxic Responses of kidney, Di dalam: Dellyani R Sari, Pengaruh Timbal $(\mathrm{Pb})$ pada Udara Jalan Tol Terhadap Gambaran Mikroskopis Ginjal dan Kadar Timbal $(\mathrm{Pb})$ dalam Darah Mencit Balb/C
Jantan, Skripsi, Semarang: Universitas Diponegoro

Suhita,Ni Luh Putu Rata., Sudira, I Wayan., Winaya, Ida Bagus Oka. 2013. Histopatologi Ginjal Tikus Putih Akibat Pemberian Ekstrak Peganggan (Centella asiatica) Peroral. Buletin Veteriner Udayana. Universitas Udayana. Denpasar-Bali. 5(2).

Swantara, I. M. D., dan Parwata, I. M. O. A. 2011. Kajian Senyawa Antioksidan Pada Rumput Laut Dari Pantai Sekitar Bali. 